\title{
Diet and risk of Type II diabetes: the role of types of fat and carbohydrate
}

\author{
F. B.Hu' ${ }^{1}$ R.M. van Dam ${ }^{2}$, S. Liu ${ }^{3}$ \\ ${ }^{1}$ Department of Nutrition, Harvard School of Public Health, Boston, Massachussetts, USA \\ ${ }^{2}$ Department of Chronic Diseases Epidemiology, National Institute of Public Health and Environment, Bilthoven, \\ the Netherlands \\ ${ }^{3}$ Division of Preventive Medicine, Brigham and Women's Hospital, Boston, Massachussetts, USA
}

\section{Abstract}

Although diet and nutrition are widely believed to play an important part in the development of Type II (non-insulin-dependent) diabetes mellitus, specific dietary factors have not been clearly defined. Much controversy exists about the relations between the amount and types of dietary fat and carbohydrate and the risk of diabetes. In this article, we review in detail the current evidence regarding the associations between different types of fats and carbohydrates and insulin resistance and Type II diabetes. Our findings indicate that a higher intake of polyunsaturated fat and possibly long-chain n-3 fatty acids could be beneficial, whereas a higher intake of saturated fat and trans-fat could adversely affect glucose metabolism and insulin resistance. In dietary practice, exchanging nonhydrogenated polyunsaturated fat for saturated and trans-fatty acids could appreciably reduce risk of Type II diabetes. In addition, a low-glycaemic index diet with a higher amount of fiber and minimally processed whole grain products reduces glycaemic and insulinaemic responses and lowers the risk of Type II diabetes. Dietary recommendations to prevent Type II diabetes should focus more on the quality of fat and carbohydrate in the diet than quantity alone, in addition to balancing total energy intake with expenditure to avoid overweight and obesity. [Diabetologia (2001) 44: 805-817]

Keywords Type II diabetes, diet, nutrition, dietary fatty acids, carbohydrates, glycemic index, insulin resistance, obesity
The prevalence of Type II (non-insulin-dependent) diabetes mellitus is increasing rapidly in the United States [1] and worldwide [2]. Prevalence of diabetes in adults in the world is estimated to reach $5.4 \%$ and the number of adults with diabetes to reach 300 million worldwide in the year 2025 [2]. The toll of diabetes on health and the economy is enormous and will continue to rise. Because there is no currently available cure for diabetes, primary prevention through diet and lifestyle modification is of paramount importance.

Although diet and nutrition are widely believed to play an important part in the development of Type II diabetes, specific dietary factors have not been clearly defined. Much controversy exists about the relation between the amount and types of dietary fat and carbohydrate and the risk of diabetes. Prevailing dietary recommendations promote low-fat, high-car- bohydrate diets for the prevention of diabetes, heart disease, and other chronic diseases [3, 4]. However, neither dietary fats nor carbohydrates are homogeneous molecules and it is now increasingly appreciated that different types of fat and carbohydrate have different effects on glucose homeostasis and insulin sensitivity. We review in detail the current evidence regarding the association between types of fat and carbohydrates and insulin resistance and Type II diabetes. We specifically discuss the roles of major types of fat, trans-fatty acids and n-3 fatty acids, as well as different types of carbohydrate and fiber, in the development of insulin resistance and Type II diabetes.

We searched the Medline database for epidemiologic investigations of the associations between dietary fat and carbohydrate and the risk of developing hyperglycaemia and Type II diabetes. We also carefully examined the cited references in the articles 
identified through a computer search to locate additional relevant metabolic and animal studies.

\section{Major types of fat in relation to insulin resistance and Type II diabetes}

Obesity predisposes to insulin resistance and is the most important determinant of Type II diabetes [5, 6]. Dietary fatty acids could affect insulin resistance independent of obesity, but the mechanism is not well understood. It is believed that the effects of dietary fatty acids are mediated through the fatty acid composition of cell membranes [7, 8]. It has been shown that the fatty acid composition of the phospholipids in the skeletal muscle cell membranes is directly related to insulin sensitivity in humans [9]. A specific fatty acid profile in cell membranes could influence insulin action through several potential mechanisms, including altering insulin receptor binding or affinity and influencing ion permeability and cell signalling [8]. Because the change of fatty acid profile in cell membranes requires at least several months [9], it is important to consider the duration of the studies when interpreting the results from feeding studies on dietary fatty acids and insulin resistance.

Dietary intervention studies. In animal studies, both the type and the amount of dietary fat have been shown to affect insulin sensitivity [10]. Several animal studies have suggested beneficial effects of monosaturated or polyunsaturated fats on insulin action [11, 12]. On the other hand, diets with a very high fat content decreased insulin sensitivity in rats. It was shown that animals fed a high-fat diet (59\% of energy supplied by fat) had decreased insulin sensitivity compared with animals fed a low-fat diet (12\% of energy intake) [10].

In contrast to the findings in rats, dietary interventions in humans showed no consistent deleterious effects of high-fat diets on insulin sensitivity. Some studies, especially the earlier studies (all less than one month), showed a decrease in insulin sensitivity in patients receiving a high-fat diet [13]. These results, however, are difficult to interpret because the order of diets was not randomized, the methods used to measure insulin sensitivity had considerable weaknesses, or there were large differences in the diets in addition to differences in fat content [13, 14]. Randomized studies using the glucose clamp or the frequently sampled intravenous glucose tolerance test (FSIGT) to measure insulin sensitivity generally did not observe an effect of high-fat diets on insulin sensitivity, despite a large range in their fat content [15-17]. Only one of these studies reported a decrease in insulin sensitivity in patients who received a high-fat diet ( $50 \%$ energy) as compared with those who received a low-fat diet ( $20 \%$ energy), possibly because of the large difference in the amount of saturated fat between the diets [18].

Several short-term intervention studies compared diets high in saturated fat with those higher in unsaturated fats and found no differences in measures of glucose homeostasis between the randomized groups [19-21]. These intervention studies were small and only 4 weeks or less in duration. A recently completed multicenter study involving 3-month intervention among 162 healthy men and women [22] showed that a diet high in saturated fat (18\% of energy) decreased insulin sensitivity compared with a diet high in monounsaturated fat ( $21 \%$ of energy) with the same total fat content. No effects on insulin secretion or glucose metabolism were observed.

Epidemiologic studies with biomarkers of specific fatty acids. Few epidemiologic studies have examined biomarkers of fatty acids as predictors of Type II diabetes. In a 10-year follow-up study [23], men who developed Type II diabetes had a higher proportion of saturated fatty acids and a lower proportion of linoleic acid in their serum cholesterol esters than did men who did not develop diabetes at baseline. Similar associations were reported for cross-sectional studies of insulin sensitivity $[24,25]$ and glucose intolerance [26]. The fatty acid composition of serum cholesterol esters reflects the average dietary fat intake in the preceding weeks [23]. Therefore, the reported associations are consistent with a detrimental effect of diets containing a high proportion of saturated fat and a low proportion of linoleic acid on the development of Type II diabetes. The findings could, however, also reflect genetic differences in enzymatic activity that can affect both insulin sensitivity and fatty acid composition [23]. Moreover, deterioration in glucose metabolism could cause changes in fatty acid composition, as insulin is known to affect the activity of desaturase enzymes [23].

Epidemiologic studies of dietary fats and insulin resistance. Several cross-sectional studies examined dietary fat in relation to fasting and post-load plasma insulin concentrations [27-33]. In general, these studies observed a positive association between saturated fat intake and hyperinsulinaemia independent of measures of body fat [28-32]. The Insulin Resistance and Atherosclerosis study included the assessment of insulin sensitivity by minimal model analysis of an intravenous-glucose tolerance test in 1173 men and women [34]. After multivariate adjustment for other determinants of insulin resistance including BMI, dietary fats (total, saturated, monounsaturated, or polyunsaturated fat) were not associated with insulin sensitivity despite the large power of the study. The only significant finding was an inverse association between polyunsaturated fat and insulin sensitivity among obese participants $(p=0.04)$. 
Intake of polyunsaturated fat was inversely associated with the area under the insulin curve in a study of 389 men [31], whereas intake of linoleic acid was positively associated with fasting insulin concentration in a study of 544 women twins [30]. A possible explanation for the inconsistent findings for polyunsaturated fat could be the lack of correction for correlated intake of other types of fat. Two studies have found a positive association between monounsaturated fat and insulin concentrations [28, 30], a finding that could be due to confounding by saturated fat because monounsaturated fat is highly correlated with saturated fat intake in a typical Western diet because of shared food sources (e.g., beef and dairy products). In one study, adjustment for saturated fat intake substantially attenuated the positive association between oleic acid (the primary mononunsaturated fat in the diet) and hyperinsulinaemia [32].

Types of dietary fat and risk of hyperglycaemia and Type II diabetes. Table 1 summarizes epidemiologic studies that examined dietary fat in relation to hyperglycaemia or risk of clinical Type II diabetes. Because patients who know their disease status might change their diet, we did not include case-control studies or cross-sectional studies that included participants with known diabetes or impaired glucose tolerance. Most of the earlier cohort studies did not observe important associations between diet and incidence of Type II diabetes [35-38]. This is not surprising given the small number of cases [35-37] or limited assessment of diet [38] in these studies. Also, the role of important risk factors for Type II diabetes such as body fat and physical activity was not taken into account in most of the analyses.

More recent prospective and cross-sectional studies were better designed and generally suggestive of a role of specific types of fat rather than of total fat in the development of Type II diabetes. A high intake of vegetable fat was inversely associated with risk of diagnosed Type II diabetes during 6 years of followup among participants of the Nurses' Health Study who were not obese [39]. Findings from this study after 14 years of follow-up with more than 2500 incident cases of diabetes confirmed this finding; high intakes of vegetable fat and polyunsaturated fat were associated with a decreased risk of Type II diabetes [40]. This association could not be explained by BMI, physical activity, alcohol intake, cigarette smoking, family history of diabetes, total energy intake, or intake of other fats. The relative risk (RR) of Type II diabetes after adjustment for these variables and other dietary fats was 0.75 (95\% CI, 0.65-0.88) for the highest quintile of polyunsaturated fat intake versus the lowest quintile. The RR comparing extreme quintiles of vegetable fat intake was 0.60 (95\% CI, $0.51-0.71 ; p<0.0001)$. A higher consumption of oils consisting primarily of polyunsaturated fat was associated with lower fasting plasma concentrations of glucose in an Italian study [41]. In contrast, one study reported a positive association between polyunsaturated fat intake and hyperglycaemia in men, although no association was observed in women [42]. In other studies, polyunsaturated fat was not associated with hyperglycaemia [43, 44] or with incidence of Type II diabetes in men [45].

Two cross-sectional studies $[43,46]$ and one small prospective study [44] suggest a positive association between saturated fat and hyperglycaemia or glucose intolerance. Several large cohort studies that used diagnosed Type II diabetes as an endpoint, however, did not observe an appreciable association with saturated fat intake [39, 40, 45]. The metabolic effects of substituting saturated fat for carbohydrate are complex. Although this kind of substitution clearly increases low-density lipoprotein LDL cholesterol [47] and could adversely affect insulin resistance as discussed above, it also increases HDL and decreases triglycerides [47], especially if high glycaemic index carbohydrate foods are replaced by saturated fat.

Except for one small study on patients with impaired glucose tolerance [48], epidemiologic studies generally did not find an association between intake of monounsaturated fat and risk of Type II diabetes $[39,44,45]$. Confounding by saturated fat could have hindered the analysis for monounsaturated fat because they are highly correlated in a typical Western diet. An interesting aspect of an Italian study was the opportunity of examining intake of monounsaturated fat with minimal confounding by intake of saturated fat because of the high consumption of olive oil [41]. Although total intake of monounsaturated fat was not estimated in the study, high consumption of olive oil was associated with lower fasting plasma glucose concentrations.

Although there is little evidence to suggest that dietary cholesterol adversely influences glucose metabolism, a positive association of cholesterol intake with hyperglycaemia [43] and diabetes risk (independent of other fats) has been reported [40]. As cholesterol is present only in animal products, these associations could represent an adverse effect of a food pattern characterized by high consumption of meat and eggs or an unidentified component of animal products. In this regard, the association between meat intake and diabetes mortality (as mentioned on death certificates) observed in the Seven Day Adventist study is of interest [49].

Available data suggest a potential beneficial effect of polyunsaturated fat and a potential adverse effect of saturated fat, although total fat does not appear to predict risk of Type II diabetes. However, the findings on types of dietary fat are not consistent. Some of the inconsistencies could be due to different study population characteristics such as age, sex, and underlying insulin resistance resulting from obesity and inactivi- 
Table 1. Epidemiologic studies of dietary fat and carbohydrate in relation to hyperglycaemia and Type II diabetes (FFQ, food frequency questionnaire; DM, diabetes mellitus; IGT, impaired glucose tolerance; OGTT, oral glucose tolerance test; NA, not available)

\begin{tabular}{|c|c|c|c|c|c|c|c|c|c|}
\hline $\begin{array}{l}\text { Year (refer- } \\
\text { ence No.) }\end{array}$ & Study & $\begin{array}{l}\text { Study size } \\
\text { (No. cases) }\end{array}$ & Sex & $\begin{array}{l}\text { Age, years } \\
\text { (baseline) }\end{array}$ & $\begin{array}{l}\text { Follow-up } \\
\text { (years) }\end{array}$ & $\begin{array}{l}\text { Diet } \\
\text { assessment }\end{array}$ & Outcome & Adjustment & $\begin{array}{l}\text { Reported associations } \\
\text { with dietary fats and } \\
\text { carbohydrate }\end{array}$ \\
\hline \multicolumn{10}{|c|}{ Prospective studies } \\
\hline $1974[38]$ & $\begin{array}{l}\text { Israeli heart } \\
\text { Disease study }\end{array}$ & 373 & $\mathrm{M}$ & $40+$ & 5 & $\begin{array}{l}\text { 'Short dietary } \\
\text { questionnaire' }\end{array}$ & Clinical DM & Not mentioned & No associations \\
\hline $1984[35]$ & $\begin{array}{l}\text { Pima Indians, } \\
\text { USA }\end{array}$ & 87 & $\mathrm{~F}$ & $25-44$ & NA & Dietary history & Clinical DM & No adjustments & $\begin{array}{l}\text { No associations with fat. } \\
\text { Positive association } \\
\text { with carbohydrate. }\end{array}$ \\
\hline 1985 [49] & $\begin{array}{l}\text { Adventists' } \\
\text { Health study, } \\
\text { USA }\end{array}$ & 278 & $\mathrm{M} / \mathrm{F}$ & $30-89$ & 21 & $\begin{array}{l}\text { FFQ (total meat } \\
\text { consumption) }\end{array}$ & $\begin{array}{l}\text { Clinical DM } \\
\text { (on death cer- } \\
\text { tificate) }\end{array}$ & $\begin{array}{l}\text { Age, body weight, } \\
\text { physical activity } \\
\text { (men only), other } \\
\text { foods }\end{array}$ & $\begin{array}{l}\text { Positive association } \\
\text { with meat intake in } \\
\text { men, but not in women. }\end{array}$ \\
\hline 1989 [37] & $\begin{array}{l}\text { Gothenburg, } \\
\text { Sweden }\end{array}$ & 43 & $\mathrm{~F}$ & $38-60$ & 12 & $\begin{array}{l}\text { 24-hr recall, } \\
\text { diet records }\end{array}$ & Clinical DM & No adjustments & No associations \\
\hline 1994 [48] & $\begin{array}{l}\text { San Luis Valley } \\
\text { Diabetes study, } \\
\text { USA }\end{array}$ & 20 & $\mathrm{M} / \mathrm{F}$ & $30-74$ & $1-3$ & 24-hr recall & DM II (OGTT) & $\begin{array}{l}\text { Age, sex, ethnicity, } \\
\text { obesity, blood } \\
\text { glucose/insulin }\end{array}$ & $\begin{array}{l}\text { Positive association } \\
\text { with fat intake }\end{array}$ \\
\hline 1989 [36] & $\begin{array}{l}\text { Zutphen study, } \\
\text { Netherlands }\end{array}$ & 58 & M & $40-59$ & 25 & $\begin{array}{l}\text { Cross-check } \\
\text { dietary history }\end{array}$ & $\begin{array}{l}\text { Clinical DM } \\
\text { (confirmed) }\end{array}$ & No adjustments & No associations \\
\hline 1992 [39] & $\begin{array}{l}\text { Nurses' Health } \\
\text { study, USA }\end{array}$ & 702 & $\mathrm{~F}$ & $34-59$ yr. & 6 & FFQ & $\begin{array}{l}\text { Clinical DM II } \\
\text { (confirmed) }\end{array}$ & $\begin{array}{l}\text { Other risk factors } \\
\text { and total energy }\end{array}$ & $\begin{array}{l}\text { Inverse association for } \\
\text { vegetable fat among } \\
\text { non-obese }\end{array}$ \\
\hline $1997[82]$ & $\begin{array}{l}\text { Nurses' Health } \\
\text { study, USA }\end{array}$ & 915 & $\mathrm{~F}$ & $40-65$ & 6 & FFQ & $\begin{array}{l}\text { Clinical DM II } \\
\text { (confirmed) }\end{array}$ & $\begin{array}{l}\text { Other risk factors } \\
\text { and total energy }\end{array}$ & $\begin{array}{l}\text { Inverse associations } \\
\text { with cereal fiber; posi- } \\
\text { tive association with } \\
\text { glycaemic load; no asso- } \\
\text { ciations with either total } \\
\text { fat or total carbohy- } \\
\text { drate }\end{array}$ \\
\hline $1997[45]$ & $\begin{array}{l}\text { Health Profes- } \\
\text { sionals Follow-up } \\
\text { Study, USA }\end{array}$ & 523 & $\mathrm{M}$ & $40-75$ & 6 & FFQ & $\begin{array}{l}\text { Clinical DM II } \\
\text { (confirmed) }\end{array}$ & $\begin{array}{l}\text { Other risk factors } \\
\text { and total energy } \\
\text { intake }\end{array}$ & $\begin{array}{l}\text { Inverse associations } \\
\text { with cereal fiber; posi- } \\
\text { tive association with } \\
\text { glycaemic load; no asso- } \\
\text { ciations with either total } \\
\text { fat or total carbohy- } \\
\text { drate }\end{array}$ \\
\hline $1995[44]$ & $\begin{array}{l}\text { Seven-Countries } \\
\text { Study, Nether- } \\
\text { lands/ Finland }\end{array}$ & 338 & M & $50-70$ & 20 & $\begin{array}{l}\text { Cross-check } \\
\text { dietary history }\end{array}$ & $2 \mathrm{~h}$ glucose & $\begin{array}{l}\text { Age, BMI, total } \\
\text { energy intake }\end{array}$ & $\begin{array}{l}\text { Positive association } \\
\text { with saturated and total } \\
\text { fat; no association with } \\
\text { total, simple, or com- } \\
\text { plex carbohydrates; in- } \\
\text { verse association with } \\
\text { fish intake }\end{array}$ \\
\hline $1991[51,86]$ & Netherlands & 59 & $\mathrm{M} / \mathrm{F}$ & $64-87$ & 4 & $\begin{array}{l}\text { Cross-check } \\
\text { dietary history }\end{array}$ & IGT/DM & $\begin{array}{l}\text { Other risk factors } \\
\text { and total energy } \\
\text { but not physical } \\
\text { activity }\end{array}$ & $\begin{array}{l}\text { Positive association } \\
\text { with total carbohydrate; } \\
\text { no association with sim- } \\
\text { ple or complex carbo- } \\
\text { hydrates; inverse associ- } \\
\text { ation with fish intake }\end{array}$ \\
\hline $2001[40]$ & $\begin{array}{l}\text { Nurses' Health } \\
\text { Study, USA }\end{array}$ & 2507 & $\mathrm{~F}$ & $34-59$ & 14 & FFQ & $\begin{array}{l}\text { Clinical DM II } \\
\text { (confirmed) }\end{array}$ & $\begin{array}{l}\text { Other risk factors, } \\
\text { total energy intake } \\
\text { and other fats }\end{array}$ & $\begin{array}{l}\text { Inverse association with } \\
\text { vegetable fat and poly- } \\
\text { unsaturated fat; positive } \\
\text { association with trans } \\
\text { fat; no association with } \\
\text { total fat }\end{array}$ \\
\hline 2000 [87] & $\begin{array}{l}\text { Iowa Women's } \\
\text { Health Study, } \\
\text { USA }\end{array}$ & 1141 & $\mathrm{~F}$ & $55-69$ & 6 & FFQ & $\begin{array}{l}\text { Self-reported } \\
\text { DM II }\end{array}$ & $\begin{array}{l}\text { Other risk factors } \\
\text { and total energy }\end{array}$ & $\begin{array}{l}\text { Inverse associations } \\
\text { with whole grain, total } \\
\text { and cereal fiber; no as- } \\
\text { sociation with glycae- } \\
\text { mic index or glycaemic } \\
\text { load }\end{array}$ \\
\hline 2000 [93] & $\begin{array}{l}\text { Nurses' Health } \\
\text { Study, USA }\end{array}$ & 1879 & $\mathrm{~F}$ & $38-63$ & 10 & FFQ & $\begin{array}{l}\text { Clinical DM II } \\
\text { (confirmed) }\end{array}$ & $\begin{array}{l}\text { Other risk factors } \\
\text { and total energy }\end{array}$ & $\begin{array}{l}\text { Inverse association with } \\
\text { whole grain consump- } \\
\text { tion }\end{array}$ \\
\hline \multicolumn{10}{|c|}{ Cross-sectional studies } \\
\hline $1990[43]$ & $\begin{array}{l}\text { Zutphen Study, } \\
\text { Netherlands }\end{array}$ & 394 & M & $50-70$ & - & $\begin{array}{l}\text { Cross-check } \\
\text { dietary history }\end{array}$ & Fasting glucose & $\begin{array}{l}\text { Age, subscapular } \\
\text { skinfold thickness, } \\
\text { total energy intake }\end{array}$ & $\begin{array}{l}\text { Saturated fat and di- } \\
\text { etary cholesterol associ- } \\
\text { ated with higher plasma } \\
\text { glucose }\end{array}$ \\
\hline
\end{tabular}


Table 1. Continued

\begin{tabular}{|c|c|c|c|c|c|c|c|c|c|}
\hline $\begin{array}{l}\text { Year (refer- } \\
\text { ence No.) }\end{array}$ & Study & $\begin{array}{l}\text { Study size } \\
\text { (No. cases) }\end{array}$ & Sex & $\begin{array}{l}\text { Age, years } \\
\text { (baseline) }\end{array}$ & $\begin{array}{l}\text { Follow-up } \\
\text { (years) }\end{array}$ & $\begin{array}{l}\text { Diet } \\
\text { assessment }\end{array}$ & Outcome & Adjustment & $\begin{array}{l}\text { Reported associations } \\
\text { with dietary fats and } \\
\text { carbohydrate }\end{array}$ \\
\hline 1995 [42] & $\begin{array}{l}\text { Hoorn Study, } \\
\text { Netherlands }\end{array}$ & 2484 & $\mathrm{M} / \mathrm{F}$ & $50-74$ & - & FFQ & $2 \mathrm{~h}$ glucose & $\begin{array}{l}\text { Other risk factors, } \\
\text { total energy intake }\end{array}$ & $\begin{array}{l}\text { Polyunsaturated fat } \\
\text { associated with higher } \\
\text { plasma glucose in men } \\
\text { only }\end{array}$ \\
\hline 1991 [46] & $\begin{array}{l}\text { San Luis Valley } \\
\text { Diabe tes Study, } \\
\text { USA }\end{array}$ & $\begin{array}{l}70 \mathrm{DM}, \\
171 \mathrm{IGT}\end{array}$ & $\mathrm{M} / \mathrm{F}$ & $30-74$ & - & 24-hr recall & $\begin{array}{l}\mathrm{DM} / \mathrm{IGT} \\
(\mathrm{OGTT})\end{array}$ & $\begin{array}{l}\text { Age, sex, ethnicity, } \\
\text { BMI, total energy } \\
\text { intake }\end{array}$ & $\begin{array}{l}\text { Positive association } \\
\text { with total fat; inverse } \\
\text { association with carbo- } \\
\text { hydrate intake }\end{array}$ \\
\hline 1990 [41] & $\begin{array}{l}\text { Italian Nine } \\
\text { Communities } \\
\text { Study }\end{array}$ & 4903 & $\mathrm{M} / \mathrm{F}$ & $20-59$ & - & Short FFQ & Fasting glucose & $\begin{array}{l}\text { Age, BMI, alcohol } \\
\text { intake, other fats }\end{array}$ & $\begin{array}{l}\text { Positive associations } \\
\text { with butter/margarine; } \\
\text { inverse associations } \\
\text { with olive oil and poly- } \\
\text { unsaturated oils }\end{array}$ \\
\hline 2000 [81] & $\begin{array}{l}\text { Zutphen } \\
\text { Elderly Study }\end{array}$ & 394 & M & $69-89$ & - & $\begin{array}{l}\text { Cross-check } \\
\text { dietary history }\end{array}$ & $\begin{array}{l}\text { Fasting and } \\
2 \mathrm{~h} \text { glucose }\end{array}$ & $\begin{array}{l}\text { Other risk factors, } \\
\text { total energy intake }\end{array}$ & $\begin{array}{l}\text { No association with the } \\
\text { dietary glycaemic index }\end{array}$ \\
\hline
\end{tabular}

ty. In addition, some studies evaluated insulin resistance rather than diabetes risk, which can also be influenced by chronic insulin demand. The inconsistencies could also be due to methodological limitations in many studies, such as absence of control for other types of fat. Confounding by other aspects of diet such as fiber is likely because diets high in saturated fat is usually accompanied by lower fiber intake.

Differences in the dietary assessment methods could have also contributed to discrepant findings. Earlier studies tended to use crude dietary assessment methods with no documented validity. In the Israeli Heart study, a validation substudy suggested that the short dietary questionnaire used in the study performed poorly as compared with a long Burke questionnaire, which could explain the lack of associations [38]. The San Luis Valley Diabetes study [48] used 24-hour diet recalls, which can represent a person's usual diet poorly [50]. Other studies used short dietary questionnaires with no reported information on validity $[41,49]$. Only a few studies have tested the validity of their dietary assessment methods [42, 44, 51]. More recent studies [40, 45], using validated FFQs and repeated measures and with large sample size, are more powerful to examine the association between diet and Type II diabetes.

\section{Long-chain n-3 fatty acids/fish consumption and Type II diabetes}

Long chain n-3 fatty acids such as eicosapentaenoic acid (EPA) and docosahexaenoic acid (DHA) are found in high concentrations in fish oil. Fish oil has been shown to have a beneficial effect on insulin sensitivity in rats [10]. In humans, studies have shown an association between the proportion of long-chain n-3 fatty acids in skeletal muscle membrane phospholipids and increased insulin sensitivity [7, 9]. Because intake of fish oil directly influences the fatty acid com- position of membrane phospholipids [10], these observations suggest that a higher intake of long chain n-3 fatty acids could be beneficial for insulin sensitivity.

Fewer studies have examined the effects of fish oil on glucose homeostasis and insulin resistance among subjects without clinical diabetes and the available data are not conclusive on the effects of fish oil on insulin resistance [52, 53]. A recent 3-month study found that addition of n-3 fatty acids to the diet had no influence on insulin sensitivity or insulin secretion [22]. But further long-term data are clearly needed. In contrast, other beneficial effects of long chain n-3 fatty acids are better established, including improvement of endothelial function, reductions in platelet aggregation and serum triglyceride concentrations and anti-arrhythmic effects [54]. Some of these effects are directly or indirectly related to insulin resistance or the metabolic syndrome.

In observational studies, it is more feasible to examine the association between long-term intake of fish oils and glucose intolerance and Type II diabetes. Unfortunately, epidemiologic data on intake of fish and n-3 fatty acids in relation to risk of diabetes are sparse. In a study of 175 elderly men and women (59 cases), an inverse association was observed between consumption of small amounts of fish and incidence of glucose intolerance (impaired glucose tolerance and diabetes combined) [51]. After adjustment for age and other risk factors (but not physical activity), the odds ratio for glucose intolerance was 0.47 (95\% CI, 0.23-0.93) for participants consuming any fish (mean daily intake $24.2 \mathrm{~g}$ ). Consistent with this finding, an inverse association between an increase in fish consumption during 20 years and 2-h postload glucose concentrations was seen among 338 participants of the Dutch and Swedish cohorts of the Seven countries study [44]. Recently, the Nurses' Health study reported a modest inverse association between fish consumption and the incidence of Type II diabe- 
tes with 14 years of follow-up, but no clear trend over the categories of intake was observed [40]. In a 10year follow-up study, the proportion of n-3 fatty acids in serum cholesterol esters was not associated with risk of diabetes [23]. In the San Luis Valley Diabetes study, intake of long-chain n-3 fatty acids was not associated with fasting plasma insulin concentrations [32]. Taken together, available evidence suggests a possible benefit of long-chain n-3 fatty acids for Type II diabetes, but the data are limited and inconsistent.

\section{Trans-fatty acids in relation to insulin sensitivity and Type II diabetes}

Trans-fatty acids are formed when vegetable or fish oils are hardened by partial hydrogenation. Metabolic studies have shown that trans-fatty acids as compared with cis unsaturated fatty acids, increase concentrations of LDL cholesterol and decrease concentrations of HDL cholesterol $[55,56]$. The observation that trans-fat inhibits the activity of desaturase enzymes has raised the hypothesis that trans-fat could also affect insulin sensitivity, as indices of delta-5 desaturase activity were associated with higher insulin sensitivity [7]. However, few studies have examined the effects of trans-fat on glucose metabolism.

In a 6-week intervention study, a diet high in transmonounsaturated fat (20\% of energy) was associated with a higher postprandial insulin response than a cismonounsaturated fat diet in 16 obese patients with Type II diabetes [57]. In a study of 14 healthy women, a 4-week diet with a lower trans-fat content $(5.1 \%$ of energy) did not result in differences in glucose or insulin response as compared with the diet with cismonounsaturated fat [58]. In the Nurses' Health study, a high intake of trans-fatty acids was associated with a higher risk of Type II diabetes during 14 years of follow-up [40]. After adjustment for BMI and other types of fat, the relative risk of diabetes was 1.31 (95\% CI, 1.10-1.56) comparing the highest quintile of intake (median $2.9 \%$ energy) with the lowest quintile (median $1.3 \%$ energy). In continuous analysis, each increase of $2 \%$ of energy from trans-fatty acids was associated with a $39 \%(95 \% \mathrm{CI}, 15 \%-67 \%)$ increase in diabetes risk. This association could represent yet another adverse health effect of trans-fat.

\section{Dietary carbohydrate and Type II diabetes}

Classifications of carbohydrates. As with dietary fat, dietary carbohydrates are not homogeneous with regard to chemical structure and biologic functions. Traditionally, carbohydrates are classified into simple or complex carbohydrates on the basis of chemical structures. Most dietary recommendations have em- phasized the use of complex carbohydrates or starches and the avoidance of simple carbohydrates or sugars based on the belief that simple sugars would be digested and absorbed more quickly and thus would induce a more rapid postprandial glucose response. $\mathrm{Nu}$ merous metabolic studies have challenged this view and it is now recognized that many starchy foods such as baked potatoes and white bread produce even higher glycaemic responses than do simple sugars [59]. To quantify different glycaemic responses induced by different carbohydrate foods, the concept of glycaemic index (GI) was developed [60-62]. The index is based on the increase in blood glucose concentrations (the area under the curve for blood glucose concentrations) after the ingestion of $50 \mathrm{~g}$ of carbohydrate from a test food as compared with a standard amount $(50 \mathrm{~g})$ of reference carbohydrate (glucose or white bread). The GI depends largely on the rate of digestion and rapidity of absorption of carbohydrate [63-65].

Despite the conceptual appeal of GI, the clinical utility of GI, especially as it pertains to mixed meals, remains controversial. Several earlier studies found no differences in glycaemic responses to mixed meals with different GIs among patients with Type II diabetes or healthy subjects [66-68]. These studies, however, have been criticized for not following standard methodology in calculating the glycaemic response to a meal [69]. Studies using standardized methodology have found an excellent correlation between the observed GI values of mixed meals and the calculated values based on individual component foods [70, 71]. Also, in controlled clinical studies [69], feeding low GI meals to patients with Type II diabetes or dislipidemia has improved glycaemic control and the lipid profile (especially reduction in triglyceride concentrations).

The GI concept and insulin resistance in feeding studies. Several animal studies have tested the effects of different types of starch in the development of insulin resistance and found that rats fed an amylopectin diet became more insulin resistant than did littermates that were fed an isocaloric diet with amylose [72]. The mechanism underlying these observations is not fully understood but could be directly related to persistent postprandial hyperinsulinaemia and hyperglycaemia resulting from a high GI diet. It is also possible that a high GI diet chronically increases insulin demand and in the long run, leads to pancreatic exhaustion.

The acute effects of low-GI diets as compared with high-GI diets on plasma insulin concentrations and C-peptide concentrations have been studied extensively in humans. Most of the studies showed a lower insulin response with a low GI meal. In a study of eight healthy subjects [70], there were substantial differences in insulin responses to six mixed meals with various GI values, and insulin response correlated 
well with the glycaemic response $(r=0.83)$. Similarly, it was found that GI values were useful in discriminating glycaemic and insulinaemic responses of mixed meals among diabetic patients [73]. A recent crossover study of 12 obese teenage boys found that a low GI meal led to lower plasma glucose and insulin response [74].

Several metabolic studies have evaluated the relatively long-term effects of low-GI diets. In a crossover study of six healthy adults over 4 weeks [75], a low-GI diet reduced 24-h urinary C-peptide concentrations by $32 \%$ as compared with a high-GI diet, whereas serum fructosamine concentrations decreased by $7 \%$. In a 4-week study of 30 patients with CHD [76], a low-GI diet improved glucose tolerance and insulin sensitivity. Insulin-stimulated glucose uptake in isolated fat cells was greater following the low-GI diet. The same group subsequently reported an improvement in insulin sensitivity, as determined by the short insulin tolerance test, with a low-GI diet among 28 premenopausal women in a 3-week randomized study [77]. Studies conducted among diabetic patients have also found improved glycaemic control with a low-GI diet $[61,78]$.

Epidemiologic studies of the GI concept and metabolic markers and Type II diabetes. In epidemiologic studies, a dietary GI is typically calculated by multiplying the percentage of total carbohydrate intake contributed by each individual carbohydrate-containing food by its GI and summing these values. Two large national surveys, one conducted in the United Kingdom [79] and the other in the United States [80], found a statistically significant inverse association between calculated overall dietary GI values and plasma HDL concentrations in free-living adults. However, in a study of 394 Dutch men aged 64 to 84 years [81], no association was observed between dietary GI and HDL, hyperglycaemia or hyperinsulinaemia.

The overall blood glucose response is determined not only by GI value of a food, but also by the amount of carbohydrate in the food. Thus, the concept of glycaemic load (GL) (the product of the GI value of a food and its carbohydrate content) has been developed to represent both the quality and quantity of the carbohydrates consumed [45, 82]. Each unit of dietary GL represents the equivalent glycaemic effect of $1 \mathrm{~g}$ of carbohydrate from white bread, which is used as the reference food. Table 2 shows GI and GL values for selected common foods [83] (The serving sizes and carbohydrate contents are from the U S Department of Agriculture [84]). Foods with high GI values as well as a high carbohydrate content, such as low-amylose white rice and baked potatoes, have the highest GL values. The GL concept could be more biologically relevant than the individual GI values because, by taking into account both quality
Table 2. Glycemic index (GI) and glycemic load (GL) of selected common foods

\begin{tabular}{|c|c|c|c|c|}
\hline Food item & $\begin{array}{l}\text { GI }^{\mathrm{a}} \\
\text { (white } \\
\text { bread = } \\
100 \text { ) }\end{array}$ & $\begin{array}{l}\text { Serving } \\
\text { size }^{\text {b }}\end{array}$ & $\begin{array}{l}\text { Grams of } \\
\text { carbohy- } \\
\text { drates per } \\
\text { serving }\end{array}$ & $\begin{array}{l}\text { GL/ } \\
\text { serving }^{\mathrm{c}}\end{array}$ \\
\hline $\begin{array}{l}\text { White rice, } \\
\text { low-amylose }\end{array}$ & 125 & 1 cup & 53 & 67 \\
\hline Baked potato & 121 & 1 & 51 & 61 \\
\hline $\begin{array}{l}\text { Corn flakes } \\
\text { breakfast cereal }\end{array}$ & 119 & 1 cup & 24 & 29 \\
\hline Jelly beans & 114 & $1 \mathrm{oz}$ & 26 & 30 \\
\hline Doughnut & 108 & 1 & 23 & 25 \\
\hline Waffle & 108 & 2 & 31 & 66 \\
\hline French fries & 107 & $4 \mathrm{oz}$ & 35 & 37 \\
\hline Graham cookies & 105 & 2 & 11 & 23 \\
\hline Honey & 104 & 1 tbsp & 17 & 18 \\
\hline Bagel & 102 & 1 & 38 & 39 \\
\hline Watermelon & 102 & 1 slice & 17 & 17 \\
\hline Carrots & 101 & $1 / 2$ cup & 8 & 8 \\
\hline White bread & 101 & 1 slice & 12 & 12 \\
\hline Wheat bread & 98 & 1 slice & 12 & 12 \\
\hline Sucrose & 92 & 1 tsp & 4 & 4 \\
\hline Raisins & 91 & $1 \mathrm{oz}$ & 22 & 20 \\
\hline Ice cream & 87 & $1 / 2$ cup & 16 & 14 \\
\hline $\begin{array}{l}\text { White rice, } \\
\text { high-amylose }\end{array}$ & 84 & 1 cup & 45 & 37 \\
\hline Orange juice & 81 & $6 \mathrm{oz}$ & 20 & 16 \\
\hline Cake & 80 & 1 piece & 36 & 29 \\
\hline Brown rice & 78 & 1 cup & 45 & 35 \\
\hline Popcorn & 78 & 1 cup & 6 & 5 \\
\hline Sweet corn & 78 & $1 / 2$ cup & 16 & 12 \\
\hline Sweet potato & 77 & 1 & 25 & 19 \\
\hline Banana & 75 & 1 & 27 & 20 \\
\hline Baked beans & 68 & $1 / 2$ cup & 27 & 18 \\
\hline Parboiled rice & 67 & 1 cup & 43 & 29 \\
\hline Grapes & 61 & $1 / 2$ cup & 14 & 9 \\
\hline Orange & 61 & 1 & 16 & 10 \\
\hline $\begin{array}{l}\text { All-Bran breakfast } \\
\text { cereal }\end{array}$ & 60 & 1/2 cup & 23 & 14 \\
\hline Apple juice & 58 & $6 \mathrm{oz}$ & 22 & 13 \\
\hline Spaghetti & 58 & 1 cup & 40 & 23 \\
\hline Apple & 51 & 1 & 21 & 11 \\
\hline Chickpeas & 47 & 1 cup & 45 & 21 \\
\hline Lentils & 40 & 1 cup & 40 & 16 \\
\hline Whole milk & 38 & 1 cup & 12 & 5 \\
\hline Kidney beans & 38 & 1 cup & 39 & 15 \\
\hline Grapefruit & 36 & 0.5 & 10 & 2 \\
\hline Fructose & 33 & 2 tbsp & 31 & 10 \\
\hline Cherries & 31 & 1 cup & 24 & 7 \\
\hline Peanuts & 20 & $1 \mathrm{oz}$ & 5 & 1 \\
\hline
\end{tabular}

a The means of GI values were taken from Foster-Powell and Miller [83].

$\mathrm{b}$ The serving sizes and grams of carbohydrate/serving are from USDA [84].

${ }^{\mathrm{c}} \mathrm{GL}$ is the product of the GI value of a food and its carbohydrate content/serving. Each unit of dietary GL represents the equivalent glycemic effect of $1 \mathrm{~g}$ of carbohydrate from white bread. 
and quantity of carbohydrates, the GL represents the overall ability of a food or diet to raise the blood glucose concentration. In a subsample of the Nurses' Health study [85], the positive association with fasting triglycerides and the inverse association with plasma concentration of HDL appeared to be stronger for dietary GL than for overall GI. Furthermore, the effects of GL were more pronounced among overweight and obese women than among lean women.

An important test of the clinical usefulness of the GI concept depends on whether it predicts longterm disease risk, especially the incidence of Type II diabetes. The influence of type and quality of Type II diabetes on risk of Type II diabetes received little attention in epidemiologic studies until recently. Several epidemiologic studies examined total amount of carbohydrate and traditional classifications of carbohydrates in relation to hyperglycaemia or risk of diabetes (Table 1) [36, 39, 45, 86, 87]. In general, neither total carbohydrate nor intake of simple sugars such as sucrose intake predicted risk of diabetes. Recently, three large cohort studies examined the association between dietary GL and incidence of Type II diabetes. In the Health Professionals' Follow-up Study [45] and Nurses' Health Study [82], the incidence of diabetes increased with higher GL especially in combination with low intake of cereal fiber. In the Nurses' Health study [82], the RR of Type II diabetes was 2.50 (95\% CI, 1.14-5.51) for women with the combination with a high GL and a low cereal fiber intake compared with the opposite extreme. Similar results were obtained from the Health Professionals' follow-up study [45]. In a recent analysis of the Iowa Women's Health study [87], however, no overall association was observed for either dietary GI or GL. But in this cohort, diet was assessed at only one point in time and the diagnosis of diabetes was based entirely on self-reports on the questionnaire without further confirmation.

In a recent analysis, a strong positive association between GL and risk of CHD was observed in the Nurses' Health study [88]. The RR (highest quintile vs. lowest quintile of GL) was $1.98(95 \%$ CI, 1.41-2.77). The increased risk was more pronounced among overweight and obese women, suggesting that the adverse effects of a high GL diet are probably aggravated by underlying insulin resistance.

Glycaemic index and obesity. Obesity (particularly abdominal adiposity) is a major cause of Type II diabetes. A purported benefit of a low-fat diet is weight loss. But the association between dietary fat and obesity is not clear [89] and long-term clinical trials have not provided convincing evidence that reducing dietary fat can lead to substantial weight loss [90]. On the other hand, cumulative evidence from experimental studies suggests a potential role of a high-GI diet on the development of obesity [91, 92]. In animal studies, high-GI diets as compared with isocaloric low-GI diets induce an increase in fat synthesis even when the total body weight remains constant [72]. A recent review showed that consumption of low-GI foods or liquids was directly associated with reduction in subsequent hunger and/or increased satiety in most of the short-term feeding studies in humans [92]. In addition, voluntary energy intake increased after consumption of high-GI meals as compared with consumption of low-GI meals [92]. These observations suggest that long-term consumption of highGI diets could promote excess energy consumption and thus contribute to weight gain or to the maintenance of excess body weight, especially among susceptible subjects (e.g., sedentary or overweight subjects) [91]. To date, no long-term studies have tested the effects of GI on weight control.

\section{Whole grain consumption and risk of Type II diabetes}

Whole grain products such as whole wheat breads, brown rice, oats, and barley tend to produce slower glycaemic and insulinaemic responses than do highly processed refined grains. Whole grains are also rich in fiber, antioxidant vitamins, magnesium, and phytochemicals. Two large prospective cohort studies of women have found an inverse association between whole grain consumption and risk of diabetes and CHD. In the Iowa Women's Health study [87], the $\mathrm{RR}$ of self-reported diabetes comparing women in the highest (median, 20.5 servings/week) versus lowest quintiles (median, 1 serving/week) of whole grain intake was $0.79(95 \% \mathrm{CI}, 0.65-0.96 ; p$ for trend $=0.009)$. The lower risk with higher intake of whole grains was independent of fiber or several other constituents of whole grains. This inverse association was confirmed in the Nurses' Health study [93]; after adjustment for age, BMI, physical activity, and other covariates, the RR of diabetes comparing extreme quintiles of whole grain consumption (medians, 2.7 servings/day in the fifth quintile vs 0.13 serving/day in lowest quintile) was 0.73 (95\% CI, $0.63-0.85 ; p$ for trend $<0.0001)$. In contrast, a higher consumption of refined grains (including sweet rolls, cakes, desserts, white bread, muffins, white rice, pizza, pancakes or waffles, refined-grain breakfast cereals) was associated with an increased risk of diabetes in the analysis adjusted for age and total energy intake, although the RR was attenuated after further adjustment for BMI. The ratio of whole grain to refined grain was related to a lower risk of diabetes, suggesting a potential benefit of replacing refined grains with whole grains. Whole grain consumption has also been inversely associated with risk of CHD $[94,95]$ and ischemic stroke [96]. 


\section{Fiber consumption and risk of Type II diabetes}

Dietary fiber includes the cell walls of plants and other indigestable components of plants. Soluble fibers (pectins, gums, mucilages, and psyllium) lower total and LDL cholesterol through increased bile acid excretion and decreased hepatic synthesis of cholesterol and fatty acids [97, 98], although the cholesterol-lowering effects are modest [99]. In addition, a high-fiber diet has been shown to improve glycaemic control and insulin response $[98,100]$. In the Coronary Artery Risk Development in Young Adults (CARDIA) study [101], a lower fiber consumption predicted higher fasting insulin concentrations and greater weight gain independent of dietary intake of total and saturated fats. Foods with intact grain cereals or a high content of viscous fiber tend to have low GI values. The correlation between dietary fiber and GI is modest $(r=0.46)$ and only $21 \%$ of GI variability in 25 tested foods could be explained by the dietary fiber content [102]. This suggests the relative independence of the GI concept and dietary fiber.

So far, three prospective cohort studies have observed an inverse association between dietary fiber consumption and risk of Type II diabetes [45, 82, 87]. In all of these studies, cereal fiber appeared to contribute most to the protective effect. For example, in the Nurses' Health study [82], the RR of diabetes comparing extreme quintiles of cereal fiber intake was 0.72 (95\% CI, 0.58-0.90; $p$ for trend $=0.001)$. The corresponding RRs were 0.87 (95\% CI, 0.70-1.08) for fruit fiber and 1.17 (95\% CI, 0.93-1.46) for vegetable fiber. Similar results were obtained from the Health Professionals' follow-up study [45]. These results are consistent with the studies that showed a stronger inverse association between cereal fiber and CHD than for fruit or vegetable fiber [103-106].

It is not clear why cereal fiber could exert more beneficial effects than other sources of fiber. A study hypothesized that the protective effect of cereal fiber could be mediated by increased concentration of magnesium and antioxidant vitamins in fiber-rich cereal products [107]. However, fruits and vegetables also contain a myriad of potentially cardioprotective compounds. Nevertheless, confounding by other nutrients such as magnesium and antioxidant vitamins that are concentrated in minimally-processed grain products cannot be ruled out. Recently, it was found [108] that fiber from whole grain, but not refined grain, was inversely associated with all-cause mortality in the Iowa Women's Health study and the study attributed the association to the presence of "nutrient-rich" fiber in whole grains. While research efforts should continue to investigate the biologic effects of different types and sources of fiber, from the point of view of the public health, an increase in total dietary fiber from different food sources (especially whole grains, fruits, vegetables, legumes, and nuts) should be encouraged.

\section{Summary and Conclusions}

Although it is generally agreed that dietary modification is an important means of preventing Type II diabetes, there exists no general consensus about the roles of dietary fat and carbohydrates. The findings of this review indicate that neither total fat nor total carbohydrate as proportions of total energy play a major part in the development of Type II diabetes in humans but that different types of fat and carbohydrates appear to be more important. In particular, a higher intake of polyunsaturated fat and possibly long-chain n-3 fatty acids could be beneficial, whereas a higher intake of saturated fat and trans-fat could adversely affect glucose metabolism. In dietary practice, exchanging nonhydrogenated polyunsaturated fat for saturated and trans-fatty acids could appreciably reduce risk of Type II diabetes. In addition, a lowGI diet with a greater amount of fiber and minimally processed whole grain products seems to improve glycaemic and insulinaemic responses and lower the risk of Type II diabetes. Evidence indicates that the traditional concept of "simple" versus "complex" carbohydrates is not useful in predicting the risk of Type II diabetes.

The clinical utility of the GI remains controversial. It is either dismissed as irrelevant indicators [109] or embraced as a sole yardstick to classify "good" or "bad" foods, especially in popular diets. Current evidence indicates that the GI is a useful concept, although the GI database needs to be further developed and refined, particularly in different populations and in the context of mixed meals. Long-term studies on the GI concept and weight control are urgently needed. Future epidemiologic studies on the association between dietary GL and the risk of Type II diabetes should include major factors that are likely to influence the GI value of a food, such as the ratio of amylose to amylopectin and cooking methods (e. g., baked vs. boiled potatoes) in the dietary assessment. Repeated measures of diet are necessary in order to assess long-term dietary patterns and reduce measurement errors because of within-person variations. Large sample sizes and long-term follow-up are needed to obtain more robust results. In dietary practice, GI values are probably most useful for selecting foods that contain a high amount of carbohydrate, especially starchy foods, but they have limited use for ranking fruits and vegetables and other foods containing small amounts of carbohydrate. In evaluating health effects of individual foods, GI values should never be used in isolation; nutrient composition of the foods and overall dietary patterns are clearly important.

The most important way to lower the risk of Type II diabetes is to avoid overweight and obesity by engaging in regular physical activity and balancing total energy intake with energy expenditure. In addition, 
available evidence suggest that modifying types of fat and carbohydrates in the diet is likely to improve insulin response and lower risk of Type II diabetes, although other dietary components such as magnesium could also play a role [87]. In particular, substituting unhydrogenated unsaturated fats (such as those in natural vegetable oils, nuts, and seeds) for saturated fat (such as those in animal products) and trans-fat (such as those in vegetable shortening and hard margarine) could substantially lower risk of Type II diabetes as well as other chronic diseases. Substituting minimally processed whole grain products for refined grains would also have substantial benefits on these diseases. Instead of simply recommending a low-fat high-carbohydrate diet, current dietary recommendations for patients with diabetes have emphasized the importance of individualizing the percent of calories from fat and carbohydrate based on clinical goals $[110,111]$. Clearly, dietary recommendations to prevent and manage Type II diabetes should focus more on the quality of fat and carbohydrate in the diet than quantity alone, in addition to total energy balance.

Acknowledgements. Dr. Hu's work is supported by an American Diabetes Association Research Award. We appreciate helpful comments by Dr. Jo Ann Manson and Walter Willett.

\section{References}

1. Mokdad AH, Ford ES, Bowman BA et al. (2000) Diabetes trends in the U.S.: 1990-1998. Diabetes Care 23: 1278-1283

2. King H, Aubert RE, Herman WH (1998) Global burden of diabetes, 1995-2025: prevalence, numerical estimates, and projections. Diabetes Care 21: 1414-1431

3. National Research Council - Committee on Diet and Health (1989) Diet and Health: Implications for Reducing Chronic Disease Risk, National Academy Press, Washington

4. U. S. Department of Agriculture - U.S. Department of Health and Human Services (2000) Nutrition and your health: Dietary guidelines for Americans. Homes and Garden Bulletin No. 232, U.S. Printing Office, Washington

5. Pi-Sunyer FX (1993) Medical hazards of obesity. Ann Intern Med 119: 655-660

6. Reaven GM (1988) Role of insulin resistance in human disease. Diabetes 37: 1595-1607

7. Pan DA, Lillioja S, Milner MR et al. (1995) Skeletal muscle membrane lipid composition is related to adiposity and insulin action. J Clin Invest 96: 2802-2808

8 . Vessby B (2000) Dietary fat and insulin action in humans. Br J Nutr [83 Suppl 1]:S91-596

9. Borkman M, Storlien LH, Pan DA, Jenkins AB, Chisholm DJ, Campbell LV (1993) The relation between insulin sensitivity and the fatty-acid composition of skeletalmuscle phospholipids. N Engl J Med 328: 238-244

10. Storlien LH, Jenkins AB, Chisholm DJ, Pascoe WS, Khouri S, Kraegen EW (1991) Influence of dietary fat composition on development of insulin resistance in rats. Relationship to muscle triglyceride and omega- 3 fatty acids in muscle phospholipid. Diabetes 40: 280-289
11. Fickova M, Hubert P, Klimes I et al. (1994) Dietary fish oil and olive oil improve the liver insulin receptor tyrosine kinase activity in high sucrose fed rats. Endocr Regul 28: 187-197

12. Lardinois CK, Starich GH (1991) Polyunsaturated fats enhance peripheral glucose utilization in rats. J Am Coll Nutr 10: 340-345

13. Swinburn BA (1993) Effect of dietary lipid on insulin action. Clinical studies. Ann NY Acad Sci 683: 102-109

14. Fukagawa NK, Anderson JW, Hageman G, Young VR, Minaker KL (1990) High-carbohydrate, high-fiber diets increase peripheral insulin sensitivity in healthy young and old adults. Am J Clin Nutr 52: 524-528

15. Howard BV, Abbott WG, Swinburn BA (1991) Evaluation of metabolic effects of substitution of complex carbohydrates for saturated fat in individuals with obesity and NIDDM. Diabetes Care 14: 786-795

16. Borkman M, Campbell LV, Chisholm DJ, Storlien LH (1991) Comparison of the effects on insulin sensitivity of high carbohydrate and high fat diets in normal subjects. J Clin Endocrinol Metab 72: 432-437

17. Swinburn BA, Boyce VL, Bergman RN, Howard BV, Bogardus C (1991) Deterioration in carbohydrate metabolism and lipoprotein changes induced by modern, high fat diet in Pima Indians and Caucasians. J Clin Endocrinol Metab 73: 156-165

18. Lovejoy JC, Windhauser MM, Rood JC, de la Bretonne JA (1998) Effect of a controlled high-fat versus low-fat diet on insulin sensitivity and leptin levels in AfricanAmerican and Caucasian women. Metabolism 47: $1520-1524$

19. Uusitupa M, Schwab U, Makimattila S et al. (1994) Effects of two high-fat diets with different fatty acid compositions on glucose and lipid metabolism in healthy young women. Am J Clin Nutr 59: 1310-1316

20. Schwab US, Niskanen LK, Maliranta HM, Savolainen MJ, Kesaniemi YA, Uusitupa MI (1995) Lauric and palmitic acid-enriched diets have minimal impact on serum lipid and lipoprotein concentrations and glucose metabolism in healthy young women. J Nutr 125: 466-473

21. Louheranta AM, Turpeinen AK, Schwab US, Vidgren HM, Parviainen MT, Uusitupa MI (1998) A high-stearic acid diet does not impair glucose tolerance and insulin sensitivity in healthy women. Metabolism 47: 529-534

22. Vessby B, Uusitupa M, Hermansen K et al. (2001) Substituting dietary saturated for monounsaturated fat impairs insulin sensitivity in healthy men and women: The KANWU study. Diabetologia 44: 312-319

23. Vessby B, Aro A, Skarfors E, Berglund L, Salminen I, Lithell H. (1994). The risk to develop NIDDM is related to the fatty acid composition of the serum cholesterol esters. Diabetes 43: 1353-1357

24. Vessby B, Tengblad S, Lithell H (1994) Insulin sensitivity is related to the fatty acid composition of serum lipids and skeletal muscle phospholipids in 70-year-old men. Diabetologia 37: 1044-1050

25. Folsom AR, Ma J, McGovern PG, Eckfeldt H (1996) Relation between plasma phospholipid saturated fatty acids and hyperinsulinemia. Metabolism 45: 223-228

26. Salomaa V, Ahola I, Tuomilehto J et al. (1990) Fatty acid composition of serum cholesterol esters in different degrees of glucose intolerance: a population-based study. Metabolism 39: 1285-1291

27. Thomas BJ, Jarrett RJ, Keen H, Ruskin HJ (1982) Relation of habitual diet to fasting plasma insulin concentration and the insulin response to oral glucose. Hum Nutr Clin Nutr 1: 49-56 
28. Maron DJ, Fair JM, Haskell WL (1991) Saturated fat intake and insulin resistance in men with coronary artery disease. The Stanford Coronary Risk Intervention Project Investigators and Staff. Circulation 84: 2020-2027

29. Parker DR, Weiss ST, Troisi R, Cassano PA, Vokonas PS, Landsberg L (1993) Relationship of dietary saturated fatty acids and body habitus to serum insulin concentrations: the Normative Aging Study. Am J Clin Nutr 58: 129-136

30. Mayer EJ, Newman B, Quesenberry CP Jr, Selby JV (1993) Usual dietary fat intake and insulin concentrations in healthy women twins. Diabetes Care 16: 1459-1469

31. Feskens EJ, Loeber JG, Kromhout D (1994) Diet and physical activity as determinants of hyperinsulinemia: the Zutphen Elderly Study. Am J Epidemiol 140: 350-360

32. Marshall JA, Bessesen DH, Hamman RF (1997) High saturated fat and low starch and fibre are associated with hyperinsulinaemia in a non-diabetic population: the San Luis Valley Diabetes Study. Diabetologia 40: 430-438

33. Mooy JM, Grootenhuis PA, de Vries H, Bouter LM, Kostense PJ, Heine RJ (1998) Determinants of specific serum insulin concentrations in a general Caucasian population aged 50 to 74 years (the Hoorn Study). Diabet Med 15: $45-52$

34. Mayer-Davis EJ, Monaco JH, Hoen HM et al. (1997) Dietary fat and insulin sensitivity in a triethnic population: the role of obesity. The Insulin Resistance Atherosclerosis Study (IRAS) Am J Clin Nutr 65: 79-87

35. Bennett P, Knowler W, Baird H, Butler W, Pettitt D, Reid J (1984) Diet and the development of non-insulin-dependent diabetes mellitus: an epidemiological perspective. In: Pozza B (ed) Diet, diabetes, and atherosclerosis. Raven Press, New York, pp109-119

36. Feskens EJ, Kromhout D (1989) Cardiovascular risk factors and the 25-year incidence of diabetes mellitus in middle-aged men. The Zutphen Study. Am J Epidemiol 130: 1101-1108

37. Lundgren H, Bengtsson C, Blohme G et al. (1989) Dietary habits and incidence of noninsulin-dependent diabetes mellitus in a population study of women in Gothenburg, Sweden. Am J Clin Nutr 49: 708-712

38. Medalie JH, Papier C, Herman JB et al. (1974) Diabetes mellitus among 10,000 adult men. I. Five-year incidence and associated variables. Isr J Med Sci 10: 681-197

39. Colditz GA, Manson JE, Stampfer MJ, Rosner B, Willett WC, Speizer FE (1992) Diet and risk of clinical diabetes in women. Am J Clin Nutr 55: 1018-1023

40. Salmeron J, Hu FB, Manson JE et al. (2001) Dietary fat intake and risk of Type II diabetes in women. Am J Clin Nutr 13: 1019-1027

41. Trevisan M, Krogh V, Freudenheim J et al. (1990) Consumption of olive oil, butter, and vegetable oils and coronary heart disease risk factors. The Research Group ATS-RF2 of the Italian National Research Council [published erratum appears in JAMA 1990 Apr;263: 1768] JAMA 263: 688-692

42. Mooy JM, Grootenhuis PA, de Vries H et al. (1995) Prevalence and determinants of glucose intolerance in a Dutch caucasian population. The Hoorn Study. Diabetes Care 18: $1270-1273$

43. Feskens EJ, Kromhout D (1990) Habitual dietary intake and glucose tolerance in euglycaemic men: the Zutphen Study. Int J Epidemiol. 19: 953-959

44. Feskens EJ, Virtanen SM, Rasanen L et al. (1995) Dietary factors determining diabetes and impaired glucose tolerance. A 20-year follow-up of the Finnish and Dutch cohorts of the Seven Countries Study. Diabetes Care 18: 1104-1112
45. Salmeron J, Ascherio A, Rimm EB et al. (1997) Dietary fiber, glycemic load, and risk of NIDDM in men. Diabetes Care 20: 545-550

46. Marshall JA, Hamman RF, Baxter J (1991) High-fat, lowcarbohydrate diet and the etiology of non-insulin- dependent diabetes mellitus: the San Luis Valley Diabetes Study. Am J Epidemiol 134: 590-603

47. Mensink RP, Katan MB (1992) Effect of dietary fatty acids on serum lipids and lipoproteins: a meta-analysis of 27 trials. Arterioscler Thromb 12: 911-919

48. Marshall JA, Hoag S, Shetterly S, Hamman RF (1994) Dietary fat predicts conversion from impaired glucose tolerance to NIDDM. The San Luis Valley Diabetes Study. Diabetes Care 17: 50-56

49. Snowdon DA, Phillips RL (1985) Does a vegetarian diet reduce the occurrence of diabetes? Am J Public Health 75: 507-512

50. Willett WC (1998) Nutritional Epidemiology, 2nd edn University Press, New York

51. Feskens EJ, Bowles CH, Kromhout D (1991) Inverse association between fish intake and risk of glucose intolerance in normoglycemic elderly men and women. Diabetes Care 14: 935-941

52. Fasching P, Ratheiser K, Waldhausl W et al. (1991) Metabolic effects of fish-oil supplementation in patients with impaired glucose tolerance. Diabetes 40: 583-589

53. Toft I, Bonaa KH, Ingebretsen OC, Nordoy A, Jenssen T (1995) Effects of n-3 polyunsaturated fatty acids on glucose homeostasis and blood pressure in essential hypertension. A randomized, controlled trial. Ann Intern Med 123: 911-918

54. Connor SL, Connor WE (1997) Are fish oils beneficial in the prevention and treatment of coronary artery disease? Am J Clin Nutr 66: 1020S-1031S

55. Ascherio A, Katan MB, Zock PL, Stampfer MJ, Willett WC (1999) Trans fatty acids and coronary heart disease. N Engl J Med 340: 1994-1998

56. Muller H, Jordal O, Seljeflot I et al. (1998) Effect on plasma lipids and lipoproteins of replacing partially hydrogenated fish oil with vegetable fat in margarine. Br J Nutr 80: 243-251

57. Christiansen E, Schnider S, Palmvig B, Tauber-Lassen E, Pedersen O (1997) Intake of a diet high in trans monounsaturated fatty acids or saturated fatty acids. Effects on postprandial insulinemia and glycemia in obese patients with NIDDM. Diabetes Care 20: 881-887

58. Louheranta AM, Turpeinen AK, Vidgren HM, Schwab US, Uusitupa MI (1999) A high-trans fatty acid diet and insulin sensitivity in young healthy women. Metabolism 48: 870-875

59. Kalergis M, Pacaud D, Yale J-F (1998) Attempts to control the glycemic response to carbohydrate in diabetes mellitus: Overview and practical implications. Canadian Journal of Diabetes Care 22: 20-29

60. Jenkins DJ, Wolever TM, Taylor RH et al. (1981) Glycemic index of foods: a physiological basis for carbohydrate exchange. Am J Clin Nutr 34: 362-366

61. Jenkins DJ, Wolever TM, Buckley G et al. (1988) Lowglycemic-index starchy foods in the diabetic diet. Am J Clin Nutr 48: 248-254

62. Jenkins DJA, Jenkins AL, Wolever TMS (1994) Low glycemic index: lente carbohydrates and physiological effects of altered food frequency. Am J Clin Nutr 59: 706S-709S

63. Wolever TMS, Jenkins DJ, Jenkins AL, Josse RG (1991) The glycemic index: methodology and clinical implications. Am J Clin Nutr 54: 846-854 
64. Brand-Miller J, Wolever TMS, Colagirui S, Foster-Powell K (1999) The glucose revolution: The authoritative guide to the glycemic index. Marlowe \& Company New York

65. Hallfrisch J, Behall KM (2000) Mechanisms of the effects of grains on insulin and glucose responses $\mathrm{J}$ Am Coll Nutr 19: 320S-325S

66. Coulston AM, Hollenbeck CB, Liu GC et al. (1984) Effect of source of dietary carbohydrate on plasma glucose, insulin, and gastric inhibitory polypeptide responses to test meals in subjects with noninsulin-dependent diabetes mellitus. Am J Clin Nutr 40: 965-970

67. Coulston AM, Hollenbeck CB, Swislocki AL, Reaven GM (1987) Effect of source of dietary carbohydrate on plasma glucose and insulin responses to mixed meals in subjects with NIDDM. Diabetes Care 10: 395-400

68. Hollenbeck CB, Coulston AM, Reaven GM (1988) Comparison of plasma glucose and insulin responses to mixed meals of high-, intermediate-, and low-glycemic potential. Diabetes Care 11: 323-329

69. Wolever TM (1997) The glycemic index: flogging a dead horse? Diabetes Care 20: 452-456

70. Chew I, Brand JC, Thorburn AW, Truswell AS (1988) Application of glycemic index to mixed meals. Am J Clin Nutr 47: 53-56

71. Wolever TM, Jenkins DJ, Vuksan V, Josse RG, Wong GS, Jenkins AL (1990) Glycemic index of foods in individual subjects. Diabetes Care 13: 126-132

72. Denyer GS, Pawlak D, Higgins J et al. (1998) Dietary carbohydrate and insulin resistance: Lessons from human and animals. Proceedings of the Nutrition Society of Australia pp158-167

73. Bornet FR, Costagliola D, Rizkalla SW et al. (1987) Insulinemic and glycemic indexes of six starch-rich foods taken alone and in a mixed meal by Type II diabetics. Am J Clin Nutr 45: 588-595

74. Ludwig DS, Majzoub JA, Al-Zahrani A et al. (1999) High glycemic index foods, overeating, and obesity. Pediatrics 103: e261-e266

75. Jenkins DJ, Wolever TM, Collier GR et al. (1987) Metabolic effects of a low-glycemic-index diet. Am J Clin Nutr 46: 968-975

76. Frost G, Keogh B, Smith D, Akinsanya K, Leeds A (1996) The effect of low-glycemic carbohydrate on insulin and glucose response in vivo and in vitro in patients with coronary heart disease. Metabolism 45: 669-672

77. Frost G, Leeds A, Trew G, Margara R, Dornhorst A (1998) Insulin sensitivity in women at risk of coronary heart disease and the effect of a low glycemic diet. Metabolism 47: 1245-1251

78. Wolever TM, Jenkins DJ, Vuksan V et al. (1992) Beneficial effect of a low glycaemic index diet in Type II diabetes. Diabet Med 9: 451-458

79. Frost G, Leeds AA, Dore CJ, Madeiros S, Brading S, Dornhorst A (1999) Glycaemic index as a determinant of serum HDL-cholesterol concentration Lancet 353: 1045-1048

80. Ford E, Liu S (2001) Glycemic index, glycemic load, and serum high-density lipoprotein (HDL) cholesterol concentration among United States adults. Arch Intern Med 161: 572-576

81. van Dam RM, Visscher AW, Feskens EJ, Verhoef P, Kromhout D (2000) Dietary glycemic index in relation to metabolic risk factors and incidence of coronary heart disease: the zutphen elderly study Eur J Clin Nutr 54: 726-731

82. Salmeron J, Manson JE, Stampfer MJ, Colditz GA, Wing AL, Willett WC (1997) Dietary fiber, glycemic load, and risk of non-insulin-dependent diabetes mellitus in women. JAMA 277: 472-477

83. Foster-Powell K, Miller JB (1995) International tables of glycemic index. Am J Clin Nutr 62: 871S-890S

84. United States Department of Agriculture (1999) USDA Nutrient Database for Standard Release, SR13, Release 13

85. Liu S, Manson JE, Stampfer MJ et al. (2001) Dietary glycemic load assessed by food frequency questionnaire in relation to plasma high-density lipoprotein cholesterol and fasting triglycerides in postmenopausal women. Am J Clin Nutr 73: 560-566

86. Feskens EJ, Bowles CH, Kromhout D (1991) Carbohydrate intake and body mass index in relation to the risk of glucose intolerance in an elderly population. Am J Clin Nutr 54: 136-140

87. Meyer KA, Kushi LH, Jacobs DR Jr, Slavin J, Sellers TA, Folsom AR (2000) Carbohydrates, dietary fiber, and incident Type II diabetes in older women. Am J Clin Nutr 71: 921-930

88. Liu S, Willett WC, Stampfer MJ et al. (2000) A prospective study of dietary glycemic load and risk of myocardial infarction in women. Am J Clin Nutr 71: 1455-1461

89. Astrup A, Ryan L, Grunwald GK et al. (2000) The role of dietary fat in body fatness: evidence from a preliminary meta-analysis of ad libitum low-fat dietary intervention studies. Br J Nutr. [83 Suppl 1]:S25-s32

90. Willett WC (1998) Is dietary fat a major determinant of body fat? [published erratum appears in Am J Clin Nutr 1999 Aug;70: 304]. Am J Clin Nutr 67: 556S-562S

91. Ludwig DS (2000) Dietary glycemic index and obesity. J Nutr 130: 280S-283S

92. Roberts SB (2000) High-glycemic index foods, hunger, and obesity: is there a connection? Nutr Rev 58: 163-169

93. Liu S, Manson JE, Stampfer MJ et al. (2000) A prospective study of whole-grain intake and risk of Type II diabetes mellitus in US women. Am J Public Health 90: 1409-1415

94. Jacobs DR, Meyer KA, Kushi LH, Folsom AR (1998) Whole-grain intake may reduce the risk of ischemic heart disease death in postmenopausal women: the Iowa Women's Health Study. Am J Clin Nutr 68: 248-257

95. Liu S, Stampfer MJ, Hu FB et al. (1999) Whole-grain consumption and risk of coronary heart disease: results from the Nurses' Health Study. Am J Clin Nutr 70: $412-419$

96. Liu S, Manson JE, Stampfer MJ et al. (2000) Whole grain consumption and risk of ischemic stroke in women: A prospective study. JAMA 284: 1534-1540

97. Anderson JW, Allgood LD, Lawrence A et al. (2000) Cholesterol-lowering effects of psyllium intake adjunctive to diet therapy in men and women with hypercholesterolemia: meta-analysis of 8 controlled trials. Am J Clin Nutr 71: 472-479

98. Anderson JW, Smith BM, Gustafson NJ (1994) Health benefits and practical aspects of high-fiber diets. Am J Clin Nutr 59: 1242S-1247S

99. Brown L, Rosner B, Willett WW, Sacks FM (1999) Cholesterol-lowering effects of dietary fiber: a meta-analysis Am J Clin Nutr 69: 30-42

100. Van Horn L (1997) Fiber, lipids, and coronary heart disease. A statement for healthcare professionals from the Nutrition Committee, American Heart Association. Circulation 95: 2701-2704

101. Ludwig DS, Pereira MA, Kroenke CH et al. (1999) Dietary fiber, weight gain, and cardiovascular disease risk factors in young adults. JAMA 282: 1539-1546 
102. Wolever TM (1990) Relationship between dietary fiber content and composition in foods and the glycemic index. Am J Clin Nutr 51: 72-75

103. Morris JN, Marr JW, Clayton DG (1977) Diet and Heart: a postscript. BMJ 2: 1307-1314

104. Rimm EB, Ascherio A, Giovannucci E, Spiegelman D, Stampfer MJ, Willett WC (1996) Vegetable, fruit, and cereal fiber intake and risk of coronary heart disease among men. JAMA 275: 447-451

105. Pietinen P, Rimm EB, Korhonen P et al. (1996) Intake of dietary fiber and risk of coronary heart disease in a cohort of Finnish men. The Alpha-Tocopherol, Beta-Carotene Cancer Prevention Study Circulation 94: 2720-2727

106. Wolk AM, Manson JE, Stampfer MJ et al. (1999) Longterm intake of dietary fiber and decreased risk of coronary heart disease among women. JAMA 281: 1998-2004
107. McCarty MF (2000) Toward practical prevention of Type II diabetes. Med Hypotheses 54: 786-793

108. Jacobs DR, Pereira MA, Meyer KA, Kushi LH (2000) Fiber from whole grains, but not refined grains, is inversely associated with all-cause mortality in older women: the Iowa women's health study. J Am Coll Nutr 19: 326S-330S

109. Coulston AM, Reaven GM (1997) Much ado about (almost) nothing [editorial; comment] Diabetes Care 20: 241-243

110. American Diabetes Association (2001) Nutrition Recommendations and Principles for People With Diabetes Mellitus. Diabetes Care 24 [suppl 1]:S44-S47

111. The Diabetes and Nutrition Study Group (DNSG) of the European Association for the Study of Diabetes (EASD) (2000) Recommendations for the nutritional management of patients with diabetes mellitus. Eur J Clin Nutr 54: 353-355 